\title{
PREDICTING USEFUL LIFE OF COCOPEAT IN A FILTER BED TREATING WASTEWATER WITH HEAVY METALS USING HYDRUS-1D
}

\author{
Jessie Samaniego ${ }^{1,2}$ and Maria Antonia Tanchuling ${ }^{2}$ \\ ${ }^{1}$ Department of Science and Technology - Philippine Nuclear Research Institute, \\ Diliman, Quezon City, Philippines, Tel: +6329296011, \\ e-mail: josamaniego@pnri.dost.gov.ph \\ ${ }^{2}$ Environmental Engineering Graduate Program, College of Engineering, \\ University of the Philippines-Diliman, Quezon City, Philippines, Tel: +6329818500, \\ e-mail: mntanchuling@up.edu.ph
}

Received Date: May 4, 2017; Revised Date: October 1, 2019; Acceptance Date: October 10, 2019

\begin{abstract}
The effectiveness of cocopeat as an adsorbent for the treatment of wastewater containing heavy metals was reported in previous studies. In this study, cocopeat was used as an adsorbent in a filter bed system treating wastewater from a small scale gold mining (SSGM) ball mill facility. A total of 6,000 L of actual SSGM wastewater collected from a ball mill facility in Paracale, Camarines Norte were used in the experimental runs. The filter bed was evaluated by determining its heavy metal removal efficiencies for 50 days at a flow rate of $40 \mathrm{~L} / \mathrm{hr}$. After the experimental runs, HYDRUS$1 \mathrm{D}$ was used to simulate the transport of lead $(\mathrm{Pb})$ in the filter bed and predict the remaining useful life of cocopeat as a heavy metal adsorbent. Lead was selected for the solute transport modeling in HYDRUS-1D since $\mathrm{Pb}$ was the highest concentration in the wastewater and also exceeded the government effluent limit. Measured data from the experimental runs and water flow parameters of cocopeat were used as input values in the simulation with varying cocopeat thickness and initial concentration flux. Results showed that by increasing the thickness of the cocopeat layer, the useful life of cocopeat in the filter bed was extended. By using the actual concentration of $\mathrm{Pb}(0.0933$ $\mathrm{mg} / \mathrm{L}$ ) in the wastewater, HYDRUS-1D was able to simulate $\mathrm{Pb}$ transport in the filter and predict that the useful life of cocopeat $50 \mathrm{~cm}$ thick treating an actual SSGM wastewater was 2.74 years.
\end{abstract}

Keywords: Cocopeat, Filter bed, Heavy metals, HYDRUS-1D, SSGM wastewater

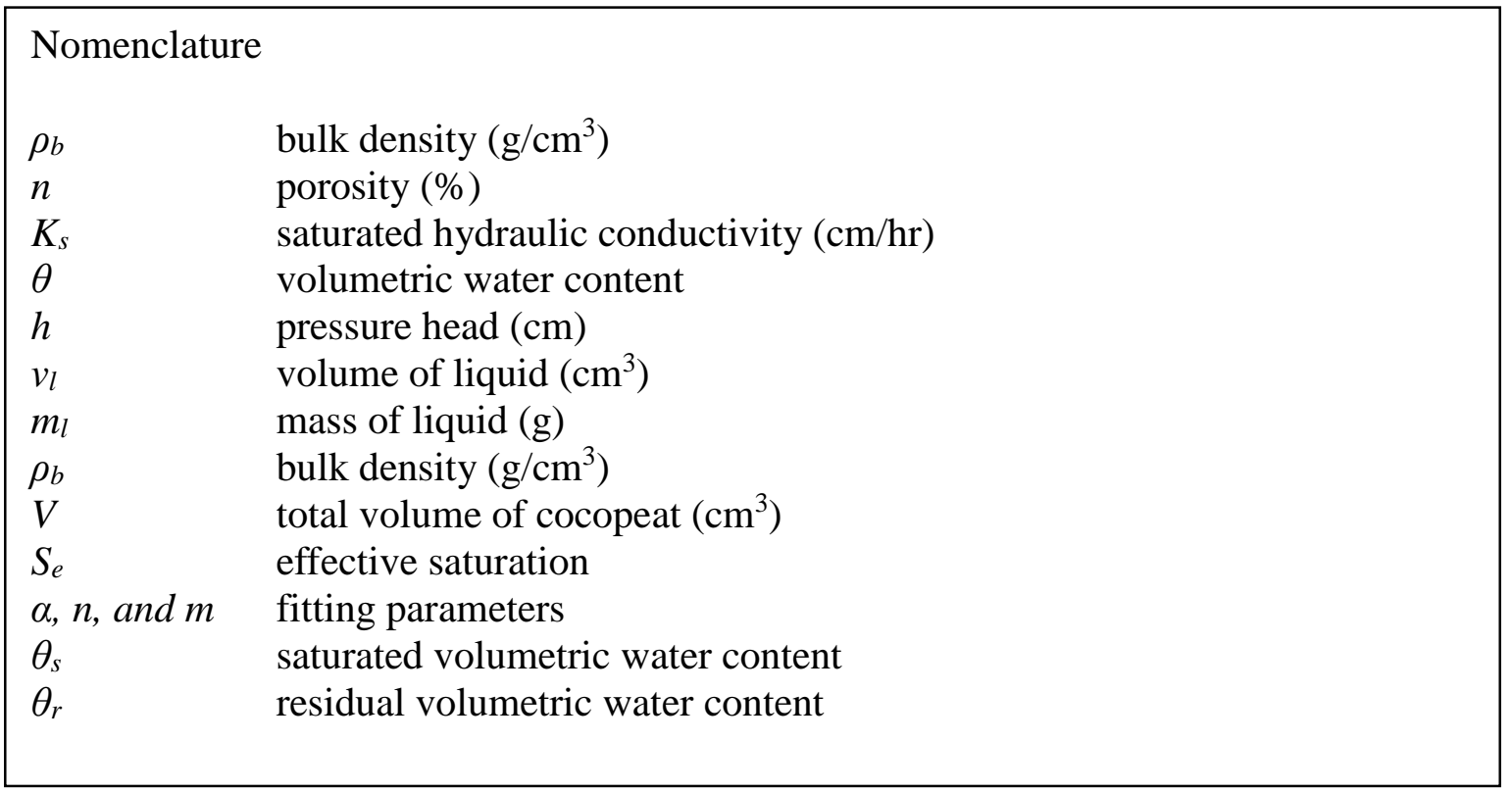




\section{Introduction}

Small scale gold miners in the Philippines and other developing countries use amalgamation process to recover gold from primary ores with the use of mercury $(\mathrm{Hg})$ $[1,2]$. This method is commonly used in gold-rush areas by small scale miners due to its simplicity in application and relatively low investment $[1,3,4]$. However, the use of amalgamation process produces wastewater with elevated amount of $\mathrm{Hg}$ and other metals as well as high concentration of suspended solids that exceed the government effluent limits [5]. Other regulated heavy metals such as arsenic (As), cadmium (Cd) and lead $(\mathrm{Pb})$ present in wastewaters from ball mill facilities in the Philippines can be traced from the chemical composition of mined ores and rocks in the mineralized areas [6]. Most of this wastewater is being disposed of to the receiving water bodies with minimal treatment or oftentimes untreated. Mercury in the wastewater, for example, can travel downstream and dispersed to a wide area of bodies of water where it can transform into methylmercury (MeHg) in the sediment of lakes and rivers. Methylmercury can be transferred and concentrated in fish which may be eaten by the people living nearby mining areas. If the workers exposed to the heavy metals in the wastewater, they have risk not only themselves to the contamination, but also their families, neighbors, and the community living near the worksites. Hence, removal of such contaminants is important before the discharge to the receiving surface waters.

In this study, adsorption was used to remove heavy metals from the wastewater because it is economical and promotes recycling and reuse of the adsorbed heavy metals $[7,8]$. It has frequently been studied and widely applied for the treatment of various heavy metal-contaminated wastewaters [9]. One of the emerging adsorbents used for heavy metal adsorption is cocopeat or coir pith. It is a short spongy fiber and dust that is a by-product in the extraction of coir fiber from coconut husks [10]. This material is cheap and abundant in the Philippines, and its use is limited only to agricultural purposes.

In the previous studies, cocopeat was used as an adsorbent for removing heavy metals from a small scale gold mining (SSGM) wastewater in batch and column experiments as well as in field scale filter bed system [11]. Characterization studies reported that cocopeat consists mainly of lignin, cellulose, hemicellulose, and some pectin and extractives (mainly fat, fatty acids, fatty alcohols, phenols, terpenes, steroids, resin acids, rosin and waxes) $[12,13]$. Previous adsorption studies suggest that heavy metals were adsorbed mainly to carboxylic (primarily present in pectin and hemicellulose but also extractives and lignin), phenolic (lignin and extractives) and to some extent hydroxylic (cellulose, hemicellulose, lignin, extractives, and pectin) and carbonyl groups (lignin) [12,14]. Laboratory scale adsorption studies were carried out to determine the efficiency of cocopeat in adsorbing zinc $(\mathrm{Zn})$ and $\mathrm{Pb}[12,15]$ from ideal aqueous solutions but very few studies performed using actual wastewater samples.

In the current study, a field scale filter bed system, composed of sedimentation tank and filter bed with cocopeat as adsorbent, was developed and tested to remove heavy metals from the actual SSGM wastewater. After the experimental runs, the transport of heavy metal in the adsorbent column is simulated by numerical computer model HYDRUS-1D - a public domain Windows-based modeling environment for analysis of water flow and onedimensional solute transport in variably saturated porous media and was first introduced in 1998 by Simunek, et.al [16]. The purpose of the study is to simulate the heavy metal transport in the cocopeat column of the filter bed, to predict adsorption capability of cocopeat over time and to determine the saturation point where the maximum adsorption of heavy metal onto the surface of cocopeat will be achieved, using HYDRUS-1D. 


\section{Materials and Methodology}

\section{SSGM Wastewater}

A total of 6,000 L of wastewater sample was gathered from the sedimentation tank of an active ball mill facility in SSGM area in Paracale, Camarines Norte, $320 \mathrm{~km}$ south of Manila. The water sample was transported to Quezon City where the pilot filter bed system was installed. Physico-chemical characteristics, such as $\mathrm{pH}$ and turbidity, were measured on site using Horiba Multi Water Quality Checker U-5000G (Japan) while total suspended solids (TSS) were measured in the laboratory using the gravimetric method after drying the sample at $105^{\circ} \mathrm{C}$. Heavy metal concentrations were analyzed using hydride generation-AAS for As; flame AAS for $\mathrm{Ba}, \mathrm{Cd}$ and $\mathrm{Pb}$; and cold vapor AAS for $\mathrm{Hg}$ following the method suggested by APHA-AWWA Standard Method for the Examination of Water and Wastewater [17]. The characteristics of SSGM wastewater used in the experiment are presented in Table 1.

Table 1. Average Heavy Metal Concentrations and Physico-Chemical Characteristics of Wastewater from The Source and After Sedimentation $(n=50)$

\begin{tabular}{lcccc}
\hline Parameter & Unit & $\begin{array}{l}\text { Wastewater from } \\
\text { the source }\end{array}$ & $\begin{array}{l}\text { Wastewater after } \\
\text { sedimentation }\end{array}$ & $\begin{array}{l}\text { DAO 2016-08 } \\
\text { Limits (Class } \\
\text { C waters) }\end{array}$ \\
\hline $\mathrm{pH}$ & unit & 6.88 & 6.59 & $6.0-9.5$ \\
$\mathrm{Turbidity}$ & $\mathrm{NTU}$ & $\geq 800$ & 76.16 & - \\
$\mathrm{TSS}$ & $\mathrm{mg} / \mathrm{L}$ & $3,816.72$ & 24.77 & 100 \\
$\mathrm{As}$ & $\mathrm{mg} / \mathrm{L}$ & 0.155 & 0.0045 & 0.04 \\
$\mathrm{Ba}$ & $\mathrm{mg} / \mathrm{L}$ & 0.154 & 0.0930 & 6.00 \\
$\mathrm{Cd}$ & $\mathrm{mg} / \mathrm{L}$ & 0.008 & 0.0020 & 0.01 \\
$\mathrm{Hg}$ & $\mathrm{mg} / \mathrm{L}$ & 0.143 & 0.0043 & 0.004 \\
$\mathrm{~Pb}$ & $\mathrm{mg} / \mathrm{L}$ & 7.938 & 0.0933 & 0.10 \\
\hline
\end{tabular}

\section{Filter Bed Materials}

Figure 1 shows the filter bed system used in the experiment. It was composed of a sedimentation tank and filter bed, both of which were made of concrete. The filter bed box was packed with gravel, cocopeat and sand layers. Gravel and sand were sieved, and the particle sizes ranging from 5-20 mm and 1-2 mm, respectively, were collected and washed with deionized water before it was stacked inside the filter bed box.

Cocopeat was sourced from the stockpiles of coconut husk decorticating plant in Sariaya, Quezon Province. The same cocopeat samples were used as an adsorbent in the previous studies on batch and column tests conducted in University of the Philippines-Diliman [11] for removing heavy metals from aqueous solutions. Long fibers and impurities were removed from cocopeat samples and were subjected to physical characterization. Parameters such as bulk density $\left(\rho_{b}\right)$, particle density, porosity $(n)$, 
saturated hydraulic conductivity $\left(K_{s}\right)$ of cocopeat were analyzed because these were needed as input parameters in HYDRUS-1D modeling. In the particle size distribution analysis, the cocopeat particle size ranged between $0.075 \mathrm{~mm}$ and $2.0 \mathrm{~mm}$, and it was characterized as sand according to the USDA textural soil classification [18].

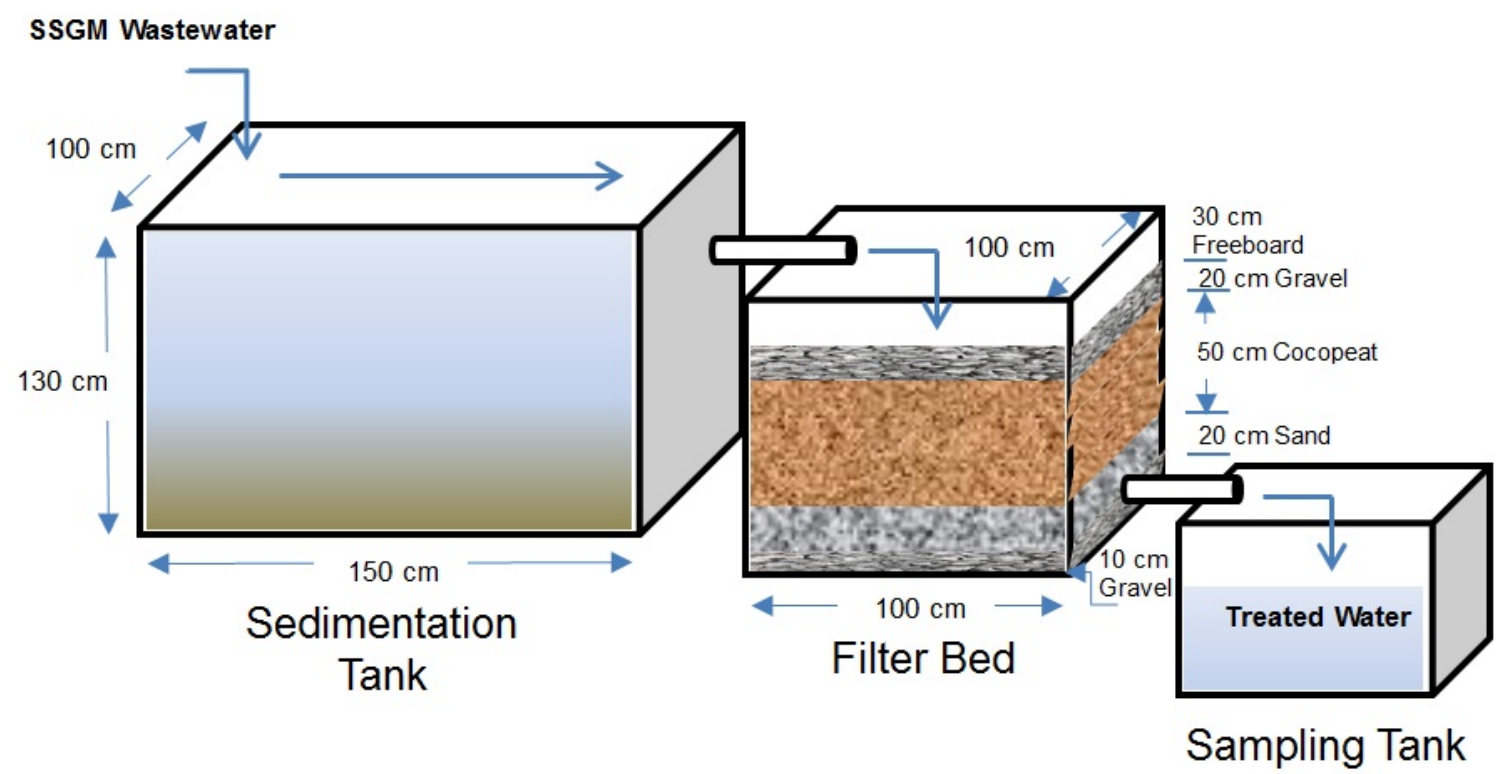

Figure 1. Sedimentation tank and cocopeat filter bed system used in the study

Table 2. Characteristics of Cocopeat Used in the Study

\begin{tabular}{lll}
\hline Parameter & Unit & Value \\
\hline Bulk density $\left(\rho_{\mathrm{b}}\right)$ & $\mathrm{g} / \mathrm{cm}^{3}$ & 0.101 \\
Particle density & $\mathrm{g} / \mathrm{cm}^{3}$ & 1.56 \\
Moisture content & $\%$ & 38.3 \\
Porosity (n) & $\%$ & 93.5 \\
Particle size (mesh) & $\mathrm{Mm}$ & $0.075-2.00$ \\
Saturated hydraulic conductivity $\left(\mathrm{K}_{\mathrm{s}}\right)$ & $\mathrm{cm} / \mathrm{hr}$ & 70.0 \\
Arsenic (As) & $\mathrm{mg} / \mathrm{kg}$ & N.D. \\
Barium (Ba) & $\mathrm{mg} / \mathrm{kg}$ & N.D. \\
Cadmium (Cd) & $\mathrm{mg} / \mathrm{kg}$ & N.D. \\
Mercury (Hg) & $\mathrm{mg} / \mathrm{kg}$ & 0.208 \\
Lead (Pb) & $\mathrm{mg} / \mathrm{kg}$ & N.D. \\
\hline
\end{tabular}

Detection limits for As, Ba, Cd, Hg and $\mathrm{Pb}$ are 0.001, 0.2, 0.003, 0.0001 and $0.01 \mathrm{mg} / \mathrm{L}$, respectively. 
Complete physico-chemical characteristics of cocopeat used in this study and heavy metal concentrations are presented in Table 2. All heavy metals, except from $\mathrm{Hg}$ with $0.208 \mathrm{mg} / \mathrm{kg}$, were not detected. The presence of $\mathrm{Hg}$ in the cocopeat sample used in the experiment can be traced from the environmental condition of stockpiles where the cocopeat is placed and stocked in an open area, and the sample is prone to sorb heavy metals including organic and inorganic Hg from different environmental media such as water, soil, vegetation and others. A total of $50.50 \mathrm{~kg}$ of cocopeat was stacked in the filter bed with the dimension of $100 \times 100 \times 50 \mathrm{~cm}(\mathrm{l} \times \mathrm{w} \times \mathrm{h})$.

\section{Operation of Filter Bed System}

SSGM wastewater samples from the site were introduced to the filter bed system for 50 days with a volume of $120 \mathrm{~L}$ per day. Wastewater was poured to the sedimentation tank with a flow rate of $40 \mathrm{~L} / \mathrm{hr}$ to undergo settling and the overflow was collected through a distribution pipe connected to the filter bed. Overflow from the sedimentation tank was introduced as influent, to the filter bed and distributed evenly with the aid of gravel layered on the top of cocopeat. The effluent flowed downward through the packed layers inside the filter bed. Treated water in the bottom was collected by drainage pipes connected to the storage tank for sample collection. After 50 days of experimental runs, cocopeat samples from 5 layers $(10,20,30,40$ and $50 \mathrm{~cm})$ along the depth of cocopeat were collected and analyzed for heavy metal concentrations to determine the distributions of the adsorbed heavy metals in the cocopeat filter bed.

\section{HYDRUS-1D Modeling}

\section{Soil Water Retention Curve}

In this study, cocopeat was categorized as sand in HYDRUS-1D computer modeling [19]. A tension plate in contact with a hanging water column was used to determine the soil water retention curve [20, 21]. The volumetric water content $(\theta)$ of cocopeat at different pressure heads $(h)$ was determined using the hanging water column technique, where $\theta$ was computed using,

$$
\theta=v_{l} / V
$$

where $v_{l}$ is the volume of liquid, which was computed by the term $v_{l}=m_{l} / \rho_{l}$, where $m_{l}$ is the mass of the liquid, $\rho_{l}$ is the density of water, and $V$ is the total volume of the cocopeat sample used. Pressure head and volumetric water content observed data by the tension plate experiment are presented in Table 3.

The collected data from hanging water column method (Table 3) were used as initial retention curve data to RETC Version 6.02 program [22] to fit a smooth curve to the observed data for HYDRUS-1D modeling. To give smooth functions of soil properties in HYDRUS-1D, the soil water retention curve equation, developed by van Genuchten in 1980 [23], was used in this study as followed;

$$
S_{e}(h)=\frac{1}{\left[1+(-\alpha h)^{n}\right]^{m}}
$$

where $S_{e}(h)$ is the effective soil water saturation and $\alpha, n$, and $m$ are fitting parameters. Effective saturation $\left(S_{e}\right)$ is expressed as; 


$$
S_{e}=\frac{\theta-\theta_{r}}{\theta_{s}-\theta_{r}}
$$

where $\theta_{s}$ is the saturated volumetric water content and $\theta_{r}$ is the residual water content. By using the two equations, and solving for $\theta(h)$;

$$
\theta(h)=\frac{\theta_{s}-\theta_{r}}{\left[1+(-\alpha h)^{n}\right]^{m}}
$$

where the relationship between $m$ and $n$ is assumed to be $m=1-1 / n$.

Cocopeat was considered as sand in the soil catalog and provided by the van Genuchten water flow parameters as $\theta_{r}(0.045 \%), \theta_{s}(0.430 \%), \alpha(0.145)$, and $n(2.680)$ except for $K_{s}(1,680 \mathrm{~cm} /$ day $)$ that was determined in the laboratory.

Table 3. Pressure Head vs Volumetric Water Content by Tension Plate Experiments

\section{Pressure Head $(h) \quad$ Volumetric Water Content $(\theta)$}

\begin{tabular}{ll}
5 & 0.7235 \\
10 & 0.6720 \\
20 & 0.5670 \\
30 & 0.5010 \\
40 & 0.4643 \\
50 & 0.4532 \\
60 & 0.4410 \\
70 & 0.4361 \\
80 & 0.4357 \\
90 & 0.4351 \\
100 & 0.4342 \\
\hline
\end{tabular}

\section{HYDRUS-1D Model Parameters}

Figure 2 shows the schematic diagram of the HYDRUS-1D modeling used in the present study. The main process of the model is to simulate a general solute transport of nonlinear cation adsorption. The soil type simulated for adsorption was the cocopeat in the filter bed with a column thickness of $50 \mathrm{~cm}$. The fitted water flow parameters from RETC program were $\theta_{r}, \theta_{s}, \alpha$, and $n$ while $K_{s}$ value was $1,680 \mathrm{~cm} /$ day. For the water flow boundary conditions; constant pressure head in the upper boundary and free drainage for lower boundary were set. The transport parameter fraction of the adsorption site of cocopeat $\rho_{b}\left(0.101 \mathrm{~g} / \mathrm{cm}^{3}\right)$ was set at 1 while longitudinal dispersivity was set at 10 . 
For the solute transport boundary conditions, the upper boundary was a concentration flux with known constant heavy metal concentration whereas the lower boundary was zero concentration gradient. In this study, $\mathrm{Pb}$ was the heavy metal under investigation since it had the highest concentration among the measured heavy metals from the SSGM wastewater (Table 1). Initial concentration of $\mathrm{Pb}$ was the average measured influent concentration in the experimental runs $\left(9.33 \times 10^{-5} \mathrm{mg} / \mathrm{cm}^{3}\right)$. Observation nodes were set at $0,10,20,30,40$ and $50 \mathrm{~cm}$. The adsorption of $\mathrm{Pb}$ onto cocopeat with respect to depth was presented with time until the entire column was filled with $\mathrm{Pb}$ concentration equal to its initial concentration.

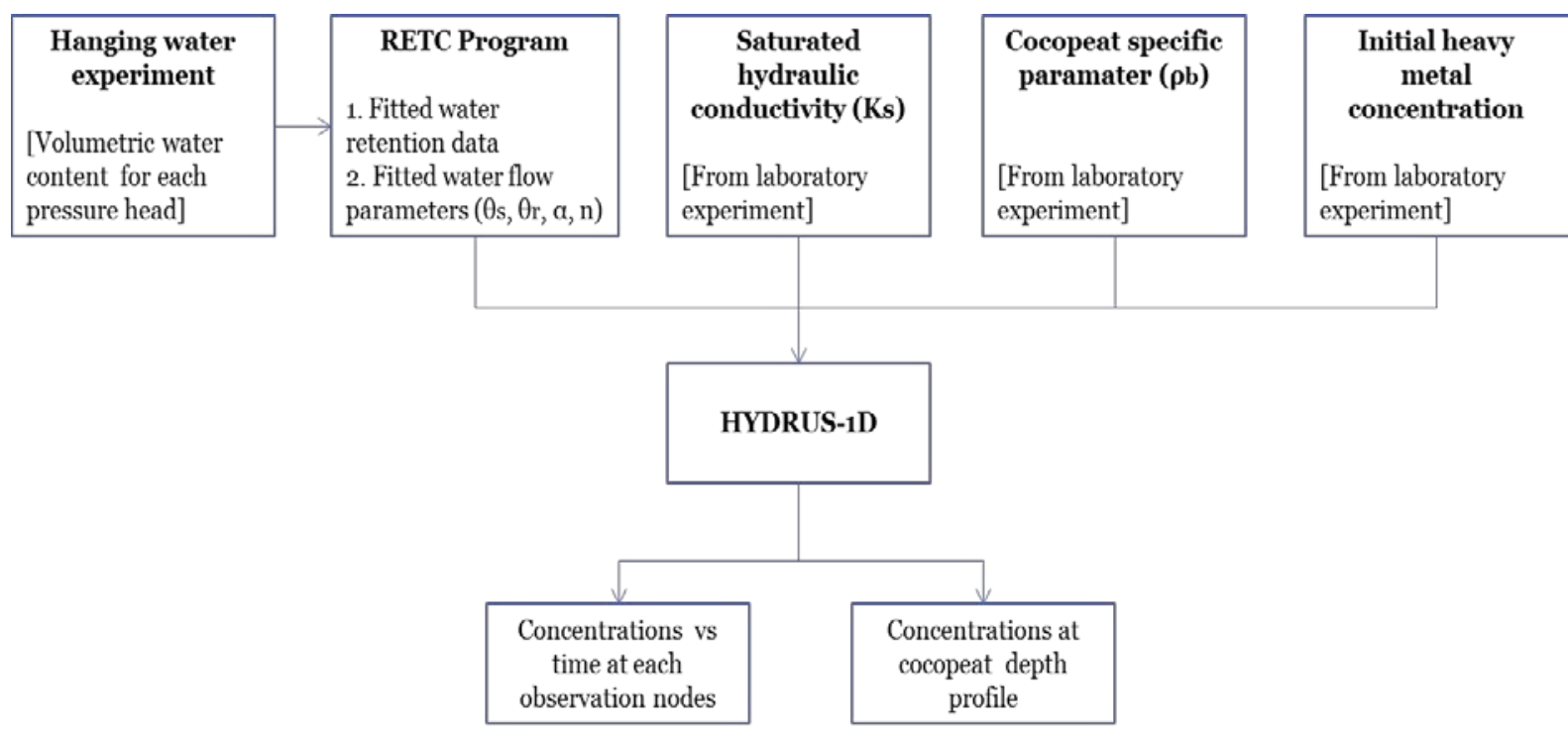

Figure 2. Schematic diagram of modeling using HYDRUS-1D

\section{Water Flow and Solute Transport Model}

HYDRUS-1D was used to simulate water flow and solute transport in variably saturated media. Transient water flow in the adsorbent domain was governed by Richards equation [20]. Solute transport equation in an unsaturated soil was obtained by combining the conservation equation, storage equation, vapor flux equation, reaction term and solute flux equation [21] In this model, water vapor phase was negligible; so the simplified solute transport equation was;

$$
\frac{\partial}{\partial t}\left(\rho_{b} C_{a}+\theta C_{l}\right)=\frac{\partial}{\partial z}\left(D_{e} \frac{\partial C_{l}}{\partial z}\right)-\frac{\partial}{\partial z}\left(J_{w} C_{l}\right)-\left(\rho_{b} r_{a}+\theta r_{l}\right)
$$

where $\rho_{b}$ is the bulk density [ $\left.\mathrm{M} \mathrm{L}^{-3}\right], C_{a}$ is the adsorbed chemical concentration $\left[\mathrm{M}_{\text {sorbent }} \mathrm{M}^{-}\right.$ ${ }^{1}$ dry soil], $\theta$ is the water content, $C_{l}$ is the dissolved chemical concentration $\left[\mathrm{M} \mathrm{L}^{-3}\right], z$ is distance [L], $D_{e}$ is the effective dispersion coefficient $\left[\mathrm{L}^{2} \mathrm{~T}^{-1}\right], J_{w}$ is the volumetric flux density $\left[\mathrm{L} \mathrm{T}^{-1}\right], r_{a}$ and $r_{l}$ is the sorbed $\left[\mathrm{M}^{-1}\right.$ soil] and dissolved $\left[\mathrm{L}^{-3}\right]$ reactions, respectively.

\section{Inverse Solution Modeling}

Inverse solution modeling was performed to come up with the fitted values of $K_{d}$ and beta (or $1 / n$ ) of $\mathrm{Pb}$ since these values were not established from batch and column adsorption experiments in the previous studies. 


\section{Direct Modeling}

The fitted values $K_{d}$ and beta (or $1 / n$ ) of $\mathrm{Pb}$ gathered from inverse solution modeling were used as input parameters for the direct modeling to determine the useful life of cocopeat. For the printing times, 50, 1,000, 2,000 and 8,000 days were set while observation nodes at the adsorbent depths were set at $0,10,20,30,40$ and $50 \mathrm{~cm}$ depths. The process of modeling solute transport with nonlinear cation adsorption was followed in the direct modeling. The final time, when the entire column was filled with the $\mathrm{Pb}$ concentration equal to its initial concentration, was considered as the time in which the filter bed was saturated and replacement of fresh cocopeat adsorbent was required.

\section{Results and Discussion}

\section{Heavy Metals Adsorbed onto Cocopeat Column}

After 50 days of operation and consuming a total of 6,000 L of raw SSGM wastewater, the measured total heavy metals adsorbed onto cocopeat were 13.20 259.20, 2.40, 25.20, and $462.00 \mathrm{mg}$ for $\mathrm{As}, \mathrm{Ba}, \mathrm{Cd}, \mathrm{Hg}$ and $\mathrm{Pb}$, respectively. Most of the heavy metals (As, Cd, Hg) were adsorbed onto cocopeat at the top $20 \mathrm{~cm}$ of the column while $\mathrm{Ba}$ and $\mathrm{Pb}$ were adsorbed at the top $30 \mathrm{~cm}$ (Figure 3a-e). The adsorption in the upper part of the column was enhanced with the presence of organic matter in cocopeat that contains polar functional groups, which dissociate and take part in metal uptake through surface complexation and exchange of metal cations [24]. Substantial concentrations of $\mathrm{Pb}$ and $\mathrm{Hg}$ observed in the lower part of the cocopeat suggest that $\mathrm{Pb}$ and $\mathrm{Hg}$ leaching occurred during the experiment. High organic carbon in cocopeat caused the possibility of $\mathrm{Hg}$ leaching from the top to bottom of the cocopeat column. The variation of concentration of $\mathrm{Pb}$ in the lower part of the cocopeat column (Figure 3e) can be attributed to the high amount of $\mathrm{Pb}$ entering the filter bed and the high affinity of $\mathrm{Pb}$ to lignin caused $\mathrm{Pb}$ ions to go deeper, as described by Guo et al. [25].

\section{HYDRUS-1D Modeling}

The flow through the soil column $(50 \mathrm{~cm})$ was calculated using fitted and measured data. For solute transport and reaction parameters, $K_{d}$ and $1 / n$ values were the fitted values from inverse modeling. The initial concentration for $\mathrm{Pb}\left(9.326 \times 10^{-5} \mathrm{mg} / \mathrm{cm}^{3}\right)$ used as a boundary condition was the average influent concentration entering the filter bed reactor during the experiment.

\section{Results of Inverse Modeling for $\mathrm{Pb}$}

After executing the HYDRUS-1D program in an Inverse Solution mode, the resultant fitted values of $K_{d}$ and beta $(1 / n)$ were $3.125 \times 10^{-4}$ and 0.948 , respectively. The fitted values $K_{d}$ and $1 / n$ for $\mathrm{Pb}$ adsorption to cocopeat in this study, together with values found in literature are presented in Table 4. Freundlich constant, $K_{d}$ fitted in HYDRUS$1 \mathrm{D}$ in this study was lower than the values found in literature, which has a range of $0.57-15.03 \mathrm{~L} / \mathrm{g}$. The lower value of $K_{d}$ in this study may be attributed to the low initial concentration of $\mathrm{Pb}$ in an actual SSGM wastewater used in the experiment as an input in the modeling, compared to the spiked concentration aqueous solution used in the laboratory experiments. The value of beta (0.95) was within the suggested empirical value of $0<\beta<1$ [26]. In addition, the fitted beta value was within the values of other studies (0.3845-1.00) on $\mathrm{Pb}$ sorption onto cocopeat that suggest a favorable adsorption. 

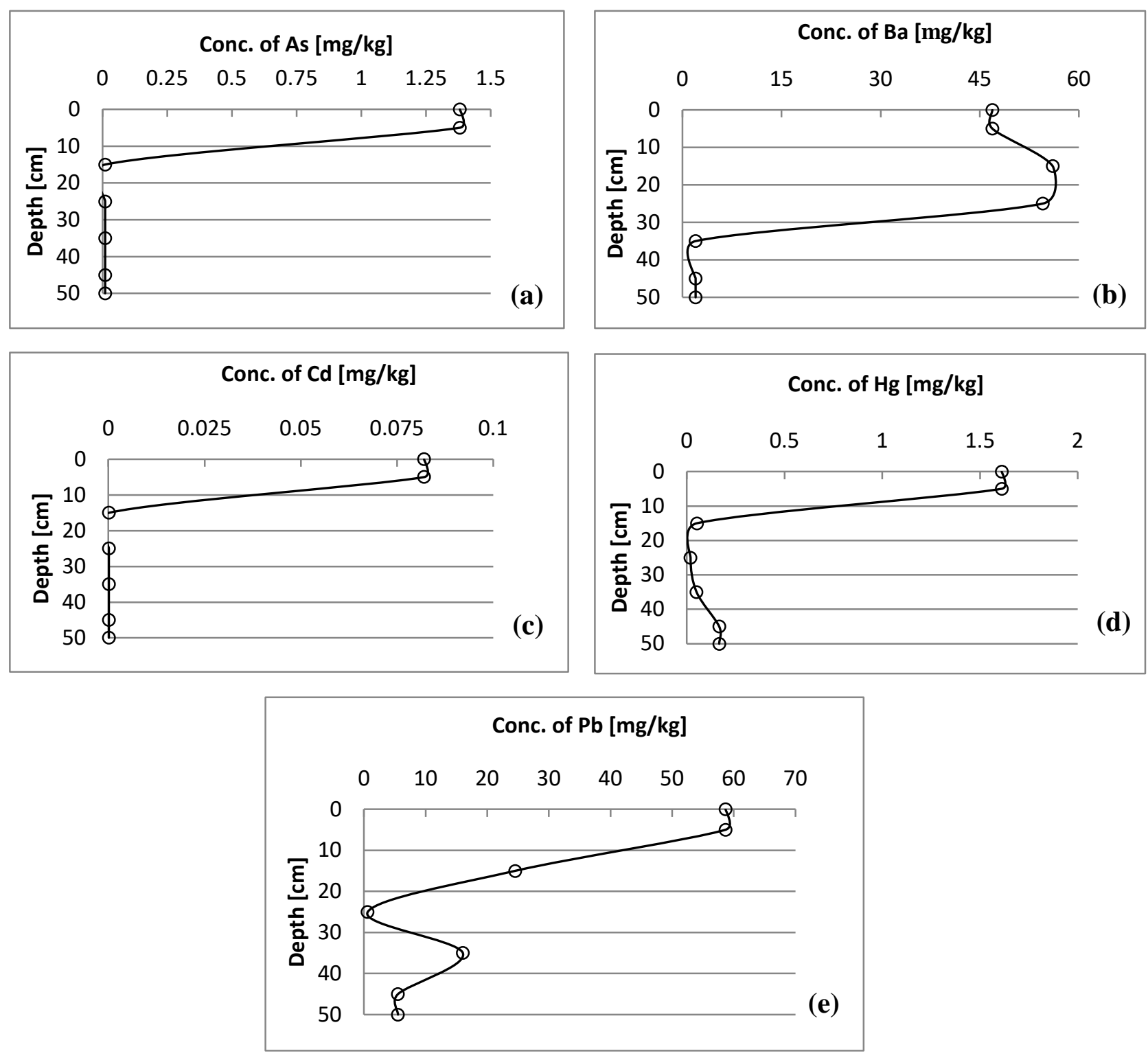

Figure 3. (a) As, (b) Ba, (c) Cd, (d) Hg, and (e) Pb concentration profiles with cocopeat depth after 50 days of operation

\section{Results of Direct Modeling for $\mathrm{Pb}$}

The results of $\mathrm{Pb}$ concentration in the column at different times are shown in Figure 4 while the concentrations in different observation points set along the column are presented in Figure 5. Regression analysis of the results between measured and predicted concentrations in the upper $20 \mathrm{~cm}$ of the column after 50 days showed high positive correlation of $R^{2}=0.86$ (Figure 6).

By examining the observation points set along the cocopeat column (Figure 5), after 2,000, 4,000 and 6,000 days, $\mathrm{Pb}$ equilibrium concentrations at the bottom (50 $\mathrm{cm}$ depth) were $2.5 \times 10^{-5}, 7.0 \times 10^{-5}$ and $8.8 \times 10^{-5} \mathrm{mg} / \mathrm{cm}^{3}$, respectively. At 8,000 days, the $\mathrm{Pb}$ concentration in the entire column was $9.326 \times 10^{-5} \mathrm{mg} / \mathrm{cm}^{3}$. This means that the cocopeat is saturated and no more adsorption occurs in the filter bed. At this period, replacement of cocopeat is recommended. When the input data measured from the experiment with daily wastewater application rate of $120 \mathrm{~L}$ and volumetric flow of $40 \mathrm{~L} / \mathrm{hr}$ were used, the useful life of cocopeat that adsorbed $\mathrm{Pb}$ onto cocopeat filtered bed with a depth of $50 \mathrm{~cm}$ was calculated at 2.74 years. 
Table 4. Values of $K_{d}$ and Beta (1/n) Constants for Pb Sorption onto Cocopeat

\begin{tabular}{lll}
\hline References & $\boldsymbol{K}_{\mathbf{d}}(\mathrm{L} / \mathrm{g})$ & $\begin{array}{c}\text { Beta } \\
\mathbf{( 1 / n )}\end{array}$ \\
\hline HYDRUS-1D Fitted (This study) & $3.125 \times 10^{-4}$ & 0.95 \\
Hazeri, et al., 2012 [15] & 2.11 & 0.65 \\
Conrad and Bruun Hansen, 2007 [12] & 2.90 & 1.00 \\
Amarasinghe, 2011 [27] & 15.03 & 0.3845 \\
Ong, 2010 [28] & 0.57 & -- \\
\hline
\end{tabular}

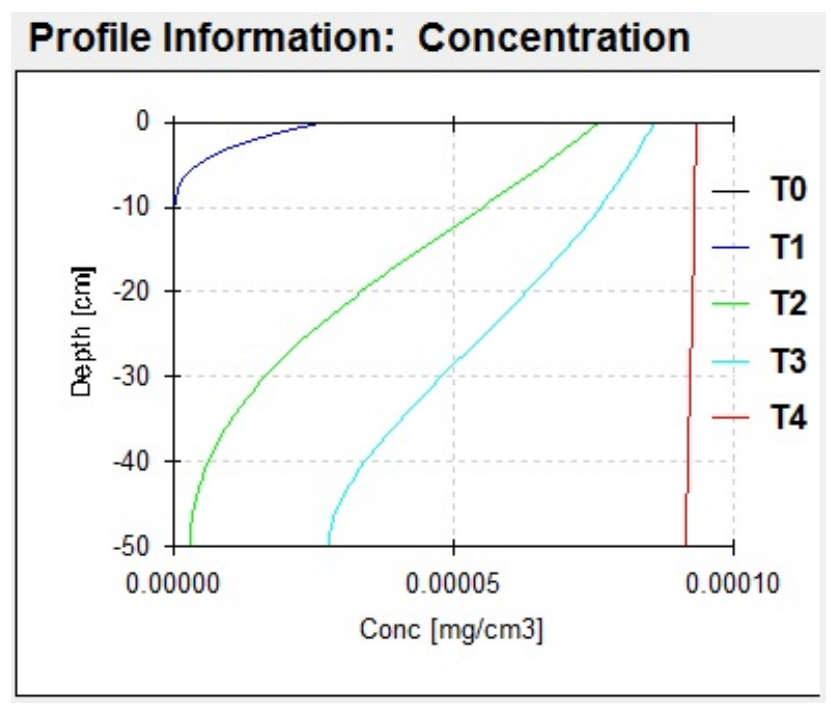

Figure 4. Profile showing $\mathrm{Pb}$ concentration along depth at $t_{0}=0$ day, $t_{1}=50$ days, $t_{2}=1,000$ days, $t_{3}=2,000$ days, and $t_{4}=8,000$ days.

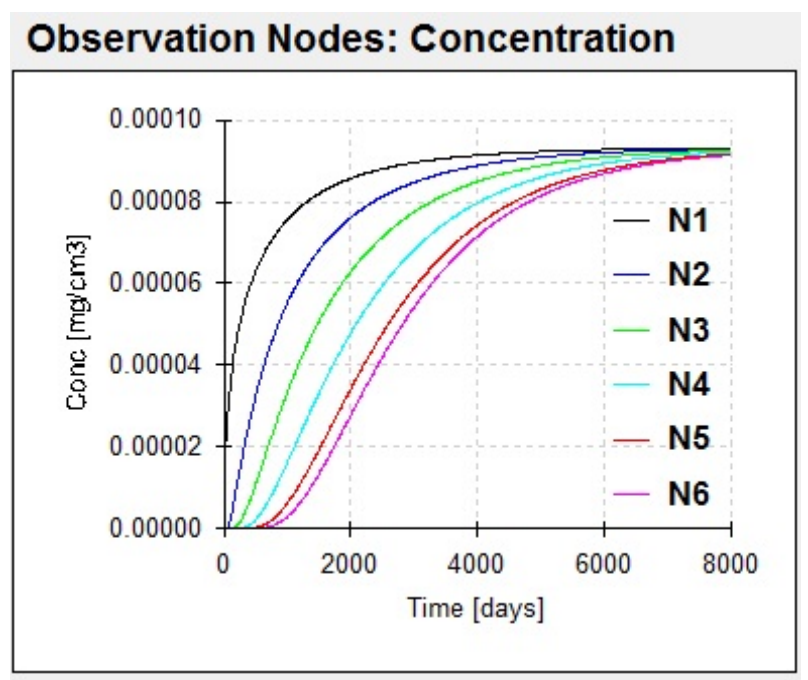

Figure 5. Observation nodes showing $\mathrm{Pb}$ concentration at $n_{1}=0 \mathrm{~cm}, n_{2}=10 \mathrm{~cm}, n_{3}=20$ $\mathrm{cm}, n_{4}=30 \mathrm{~cm}, n_{5}=40 \mathrm{~cm}, n_{6}=50 \mathrm{~cm}$. 
Based on the results given by HYDRUS-1D using the parameters in this study, the life span of cocopeat can be managed by decreasing or increasing the amount of cocopeat to be put in the filter bed. Given the depth of cocopeat, its useful life in years can be estimated using the trendline in Figure 7 or using the generated equation, $y=0.055 x$, where $y$ is the useful life, and $x$ is the depth of the cocopeat. This assumption was based on a $1 \mathrm{~m} \mathrm{x} 1 \mathrm{~m}$ filter bed area and same depth of substrates used in this study. Depth of the filter bed reactor increases depending on the thickness of cocopeat stacked.

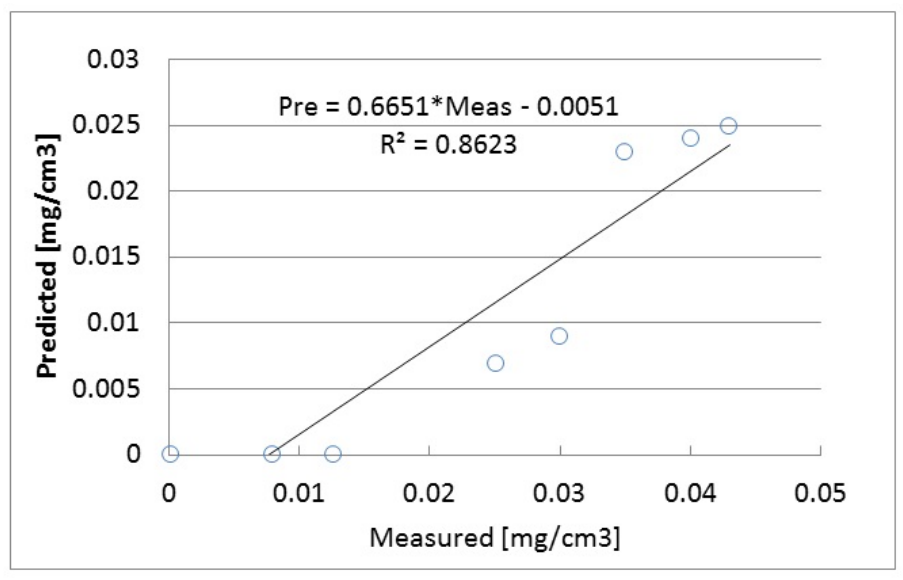

Figure 6. Predicted vs measured concentrations along cocopeat column after 50 days of operation

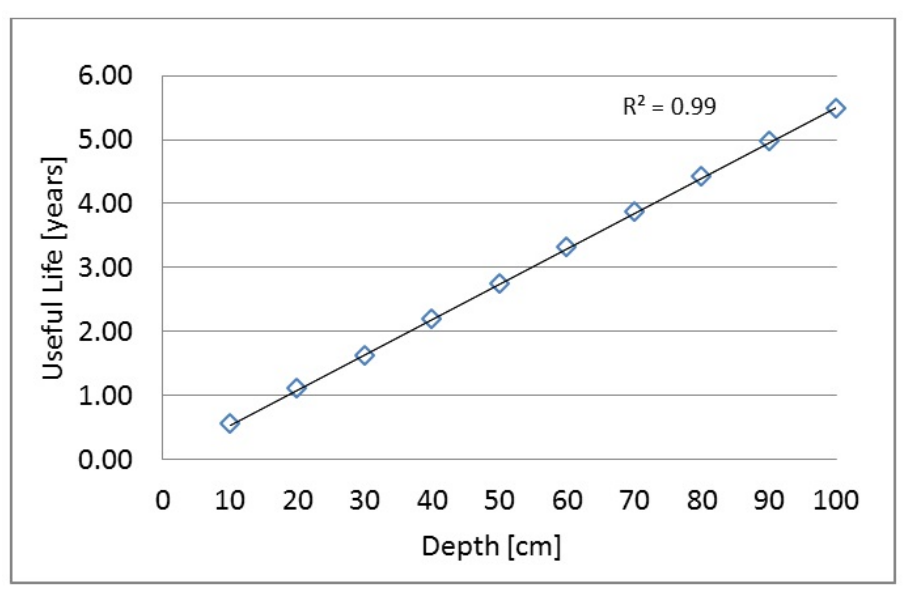

Figure 7. Thickness of cocopeat $(\mathrm{cm})$ and its corresponding useful life (years)

\section{Conclusions}

In this study, a filter bed system composed of sedimentation and cocopeat filter bed was found suitable treatment system to remove heavy metals ( $\mathrm{As}, \mathrm{Ba}, \mathrm{Cd}, \mathrm{Hg}$, and $\mathrm{Pb}$ ) from an actual SSGM wastewater. With the application of hydrologic and flow parameters, depth of cocopeat, and reaction parameters from previous studies, HYDRUS-1D was able to simulate and predict that the useful life of cocopeat in a $1 \mathrm{~m}$ x $1 \mathrm{~m}$ x $0.50 \mathrm{~m}$ filter bed was 2.74 years for $\mathrm{Pb}$. Measured and predicted concentrations in the upper $20 \mathrm{~cm}$ of the column after 50 days showed high positive correlation $\left(\mathrm{R}^{2}=0.86\right)$. Using the design parameters developed in this study, HYDRUS$1 \mathrm{D}$ was able to determine the extended useful life of cocopeat by increasing the thickness of the cocopeat at a rate of $y=0.055 x$, where $y$ is the useful life and $x$ is the depth of the cocopeat. 


\section{Acknowledgment}

Acknowledgment is given to the DOST-PCIEERD for funding the project and special credit to the Department of Science and Technology - Engineering Research and Development for Technology (DOST-ERDT) for the scholarship grants and additional research fund for the study.

\section{References}

[1] D.C. Israel, and J.P. Asirot, Mercury Pollution Due to Small-Scale Gold Mining in the Philippines: An Economic Analysis, Research Paper Series No. 2002-02, Philippine Institute for Development Studies, Makati City, Philippines, 2002.

[2] P.C. Velasquez-Lopez, M.M. Viega, and K. Hall, "Mercury balance in amalgamation in artisanal and small-scale gold mining: Identifying strategies for reducing environmental pollution in Portovelo-Zaruma, Ecuador," Journal of Cleaner Production, Vol. 18, No. 3, pp. 226-232, 2010.

[3] J.J. Hinton, M.M. Viega, and A.T.C. Viega, "Clean artisanal gold mining: A utopian approach?,” Journal of Cleaner Production, Vol. 11, No. 2, pp. 99-115, 2003.

[4] E. Bugnosen, Country Case Study on Artisanal and Small-Scale Mining: Philippines, Mining, Minerals and Sustainable Development No. 83, International Institute for Environment and Development, London, United Kingdom, 2001.

[5] Department of Environment and Natural Resources (DENR), Water Quality Guidelines and General Effluent Standards of 2016 (DENR Administrative Order No. 2016-08), Quezon City, Philippines, 2016.

[6] R. Soriano, and V. Soriano, "Process water use and water quality in selected small scale gold processing sites in the Philippines," Philippine Engineering Journal, Vol. 38, No. 2, pp. 79-98, 2017.

[7] K. Santhy, and P. Selvapathy, "Removal of heavy metals from wastewater by adsorption on coir pith activated carbon," Separation Science and Technology, Vol. 39, No. 14, pp. 331-335, 2004.

[8] N. Das, R. Vimala, and P. Karthika, "Biosorption of heavy metals-An overview," Indian Journal of Biotechnology, Vol. 7, No. 2, pp. 159-169, 2008.

[9] M.A. Barakat, "New trends in removing heavy metals from industrial wastewater," Arabian Journal of Chemistry, Vol. 4, No. 4, pp. 361-377, 2011.

[10] Philippine Coconut Authority, Utilization of Cocopeat in Coconut Production (Techno Guide Sheet No. 10), Quezon City, Philippines, 2003.

[11] M.A.N. Tanchuling, A.C. Resurreccion, and D. Ong, "A research project removing heavy metals from wastewater of small-scale gold miners of Camarines Norte (Philippines) using coco-peat as sorbent material," ASEAN Engineering Journal Part C, Vol. 1, No. 1, pp. 23-29, 2012.

[12] K. Conrad, and H.C. Bruun Hansen, "Sorption of zinc and lead on coir,” Bioresource Technology, Vol. 98, No. 1, pp. 89-97, 2007.

[13] M. Abad, P. Noguera, R. Puchades, A. Maquieira, and V. Noguera, "Physico-chemical and chemical properties of some coconut coir dusts for use as a peat substitute for containerised ornamental plants,” Bioresource Technology, Vol. 82, No. 3, pp. 241245, 2002.

[14] B.G. Lee, and R.M. Rowell, "Removal of heavy metal ions from aqueous solutions using lignocellulosic fibers,” Journal of Natural Fibers, Vol. 1 No. 1, pp. 97-108, 2004.

[15] A. Shakeri, N. Hazeri, J. Vlizadeh, E. Hashemi, and A.R. Motavalizadeh Kakhki, "Removal of lead (II) from aqueous solution using cocopeat: An investigation on the 
isotherm and kinetic,” Iranian Journal of Chemistry \& Chemical Engineering,Vol. 31, No. 3, pp. 45-50, 2012.

[16] J. Šimůnek, M. Sejna, and M.Th. van Genuchten, The HYDRUS-1D Software Package for Simulating the One-dimensional Movement of Water, Heat, and Multiple Solutes in Variably Saturated Media, Version 2.0, IGWMC-TPS-70, International Ground Water Modeling Center, Colorado School of Mines, Golden, Colorado, United States, 1998.

[17] L.S. Clesceri, A.E. Greenberg, and A.D. Eaton, eds., Standard Methods For the Examination of Water and Wastewater, $20^{\text {th }}$ Edition, American Public Health Association, Washington D.C., United States, 1998.

[18] United States Department of Agriculture (USDA), and Soil Conservation Service, Soil Mechanics Level I, Module 3 USDA Textural Soil Classification Study Guide, United States Department of Agriculture, Washington, D.C., United States, 1987.

[19] J. Simunek, M. Sejna, and M.Th. van Genuchten, HYDRUS-1D, Version 4.14 - Code for Simulating the One-Dimensional Movement of Water, Heat, and Multiple Solutes in Variably Saturated Porous Media [Online]. Available: https://www.pcprogress.com/en/Default.aspx?hydrus-1d [Accessed: August 2015].

[20] D.E. Radcliffe, and J. Simunek, Soil Physics with HYDRUS: Modeling and Applications, CRC Press, Boca Raton, Florida, United States, 2010.

[21] W.A. Jury, and R. Horton, Soil Physics, $6^{\text {th }}$ Edition, John Wiley \& Sons, Inc., New York, United States, 2004.

[22] M.Th. van Genuchten, J. Simunek, F. J. Leij, M. Sejna. RETC for Windows, Version: 6.02, 1998. Retrieved from https://www.pc-progress.com/en/Default.aspx?retc, https://www.pc-progress.com/en/Default.aspx?retc-downloads

[23] M.Th. van Genuchten, "A closed form equation for predicting the hydraulic conductivity of unsaturated soils," Soil Science Society of America Journal, Vol. 44, No. 5, pp. 892-898, 1980.

[24] S.M. Hasany, and R. Ahmad, "The potential of cost-effective coconut husk for the removal of toxic metal ions for environmental protection," Journal of Environmental Management, Vol. 81, No. 3, pp. 286-295, 2006.

[25] X. Guo, S. Zhang, and X. Shan, “Adsorption of metal ions on lignin,” Journal of Hazardous Materials, Vol. 151, No. 1, pp. 134-142, 2008.

[26] P. Loll, and P. Moldrup, Soil Characterization and Polluted Soil Assessment, Aalborg University, Aalborg, Denmark, 2000.

[27] B.M.W.P.K. Amarasinghe, "Lead and cadmium removal from aqueous medium using coir pith as adsorbent: Batch and fixed bed column studies," Journal of Tropical Forestry and Environment, Vol. 1, No. 1, pp. 36-47, 2011.

[28] D. Ong, Removal of Heavy Metals from Single Species and Composite Species Aqueous Solutions Using Coco Peat as Sorbent Material, Thesis (Master's), University of the Philippines-Diliman, Quezon City, Philippines, 2010. 